\title{
Assessing the Contribution of Inflow of Foreign Direct Investment (FDI) in the Creation of Employment Opportunities to the People in Zanzibar A Case of Tourism Sector
}

\author{
Juma Said Ali (Bahogo) Zulfa Ngude \\ Centre for Foreign Relations,Dar es Salaam, Tanzania.,P.O.BOX, 2101, Zanzibar \\ E-mail: jumasali2011@gmail.com
}

\begin{abstract}
The main objective of this study is assessing the contribution of inflow of Foreign Direct Investment (FDI) in the creation of employment opportunities to the people in Zanzibar: Tourism sector being a case study. The methods used in the study was descriptive case study design, where by questionnaires were distributed to the 50 respondents, among them were people at Nungwi village, officials from Zanzibar Investment Promotion Agency (ZIPA) and managers from hotels in Zanzibar, also documentation and observation methods were used in the collection of data. The results show that $62 \%$ were benefited being employed in the tourism sector and their income have up for $60 \%$, whereby before employment their income were lower for $80 \%$. The report concludes that FDI inflow especially in the tourism sector has brought much positive impact in the creation of employment opportunities to the people in Zanzibar. In that case it is recommended that Revolutionary Government of Zanzibar should improve and promote policies guiding tourism sector investment in the country so as fully provide more employment opportunities and improve the countries' economic development for the purposes of poverty reduction.
\end{abstract}

\section{INTRODUCTION}

Foreign Direct Investment (FDI) is the ownership of and control of foreign assets. In practice, FDI usually involves the ownership of. Whole or partial, of a company in a foreign country. This is called foreign subsidiary (Rugman, etal, 2009).This equity investment can take a variety of forms. One is through the purchase of an ongoing company. For example, Solectron, the world's largest contract electronics firm, bought C-Mac Industries of Canada in order to acquire C-Mac's expertise in assembling high-end telecommunication and networking systems. ( ibid) Rather than building this business from scratch, Solectron bought its way into the industry through FDI. African countries depend greatly on foreign direct investments (FDIs) inflows from the traditional FDI triad sources of North America, Europe and Asia especially Japan. These are mainly resource seeking, marketing-seeking and efficiency-seeking. They enter the continent through various entry modes as documented in Ngowi (2002, 2011b). The entry modes include Meagre and Acquisitions (M\&As), Greenfield investments and brow field investments (Ngowi, 2012).

Since 1986, Tanzania has embarked into various economic reforms which aimed to transform the economy from centrally planned public owned economy into market driven private sector led economy. The government recognises that it has the role to facilitate the private sector and other economic agents to actively and effectively invest in productive and commercial activities in order to accelerate economic growth and development. The Government do this mainly through putting favourable policies in place, provision of a conducive investment environment for local and foreign investment, promotion of institutional changes conducive to the development of the private sector, stimulating investor's confidence through transparent, effective and efficient administrative processes in government institutions and to put in place an appropriate legal and regulatory framework. The major policy and structural reforms carried out played a significant role in improving the business and investment environment in the country (Mathew, 2012). Various economic reforms undertaken by the government aimed to put in place laws and policies that will facilitate conducive investment environment for local and foreign projects.

Tanzania is implementing a program of economic growth and diversification in which tourism is a priority sector. The Multilateral Investment Guarantee Agency (MIGA), which is a member of the World Bank Group, was invited to partner with the Government of Tanzania and the Development Bank of Southern Africa (DBSA) to identify investment opportunities in tourism and to help promote the sector to investors (URT, 2012). The present Mainland Government laid out its policies for the tourism sector in two documents prepared for the recent election. The "Election Manifesto, October 2000",states: "in the coming 5 years, CCM Government will give special attention to improving tourism services in order to earn more income from the sector. CCM Government will continue to improve tourism-related infrastructure and invite investors into this sector." Looking forward in the document: "CCM Policy in the year 2000 - 2010", the Government stated: "The tourism sector appears to contribute a significant amount to the development of our National Income. In the next 
ten years we have to focus on improving tourism services both on the Mainland and in Zanzibar and expanding our capacity to handle more tourists and increase revenues, There is a need to design packages that will attract domestic tourists who should be enabled to enjoy the natural beauty of their country, There is also a need to improve access and develop strategies for Tanzanians to participate in the sector and provide services for tourists, The most attractive natural resources are those that are untouched. So, the effort to attract tourists should be accompanied by environmental protection measures for game parks, forests, beaches and lakes. As elaborated in Annex II, the Mainland Government undertook a number of structural and institutional reforms of interest to tourism in 2000/01 and recognizes that the business environment still requires further improvement. Its recent request for an update of the 1996 Master Plan, together with the presence of a full-time EU-financed technical expert in the Directorate of Tourism, as well as its interest in a MIGA-sponsored investment forum for tourism, clearly demonstrate the Government's realization of tourism's current and potential economic benefits.

The Government of Zanzibar stated its support for tourism in: "A Guide to Investing in Zanzibar and Investment Opportunities", issued by the Zanzibar Investment Promotion Agency (ZIPA). Tourism heads the list of six such opportunities, with the justification that: "In the recent past, the economic activity of Zanzibar was largely driven by agriculture, which, in all its facets, constitutes the mainstay of the economy. Tourism has also been buoyant and complementary to agriculture. Zanzibar has a very alluring appeal to international tourists

The government wishes to consolidate and build on these positive factors and successes of this economic sub-sector attained so far, by strongly encouraging foreign direct investment and mobilising domestic private resources to channel into up-market facilities better equipped to cater for more discerning international visitors." The Government's Tourism and Vision 2000-2020 report calls for wise utilization of available tourism resources, diversification of and improvement of assets in order to attract a diverse tourism segments and markets. It also underlines the importance of improved infrastructure and better education and capacity building for Zanzibaris to make their islands a tourist destination in their own right (URT, 2012).

\section{Statement of the Problem}

Earnings from tourism look impressive, but one would like to know more about its economic implications before concluding that, this is a positive development that should be promoted. One would like to know the employment benefits from tourism. Hitherto no study that has been revealed showing the contribution of FDI in the tourism sector in the creation of employment opportunities to the people, specifically in Zanzibar whereas the researcher aiming at assessing this end

\section{Objectives of the Study}

\subsubsection{The main Objective}

The main objective of the study is to assess the contribution of inflow of Foreign Direct Investment (FDI) in the creation of employment opportunities to the people in Zanzibar. Tourism Sector being a case study.

\section{Specific Objectives}

i. To investigate if the investment done in the tourism sector has contributed in the creation of employment opportunities to the people;

ii. Identify factors, which could help the Revolutionary Government of Zanzibar to maximise economic gains from tourism sector and minimise economic losses from it;

iii. Analyse public costs involved in tourism sector investment in the country

\section{Research Questions}

- Is investment in tourism sector has any contribution in the creation of employment opportunities to the people?

- What are the factors which could help the Revolutionary Government of Zanzibar to maximise its economic gains from tourism sector and minimise its economic losses from it?

- What are the public costs involved in tourism sector investment?

\section{Identified gap}

Although many studies have been reviewed, however the researchers have not yet recognized study that has been revealed showing the contribution of FDI in the tourism sector in the creation of employment opportunity to the people, specifically in Zanzibar whereas the researcher aiming at assessing this end.

\section{Significance of the Study}

The significance of the problem arises from the intended goal of trying to quantify the economic contributions of tourism in Zanzibar and their contribution towards employment creation. In so doing, the study sheds light on what the government can do to maximise benefits on the employment opportunity to the people. This is in line 
with the government's objective of trying to ensure that the tourism industry is elevated to a giant contributor to the national economy by not just realising high income figures but also making sure that the host country benefits. The study is also significant due to its endeavour to identify and suggest ways in which tourism can be used to contribute towards poverty alleviation as the way to reach its Millennium Development Goals (MDGs).

\section{Research design}

The researcher used descriptive case study design in order to gain rich understanding of the context of the research, developing skills of evaluating data and synthesizing ideas. This design will help the researcher to produce accurate representation of the target population. The study will be administered through interviews, structured questionnaire and documentation. The data related to FDI impact on employment in tourism sector will be collected through interviews and questionnaires and the remaining will be available through documentation.

\section{LITERATURE REVIEW}

What is Foreign Direct Investment (FDI?)

According to the IMF and OECD (2003) definitions, direct investment reflects the aim of obtaining a lasting interest by a resident entity of one economy (direct investor) in an enterprise that is resident in another economy (the direct investment enterprise). The "lasting interest" implies the existence of a long-term relationship between the direct investor and the direct investment enterprise and a significant degree of influence on the management of the latter. Direct investment involves both the initial transaction establishing the relationship between the investor and the enterprise and all subsequent capital transactions between them and among affiliated enterprises4, both incorporated and unincorporated. It should be noted that capital transactions which do not give rise to any settlement, e.g. an interchange of shares.

Foreign direct investment (FDI) is a direct investment into production or business in a country by an individual or company of another country, either by buying a company in the target country or by expanding operations of an existing business in that country. Foreign direct investment is in contrast to portfolio investment which is a passive investment in the securities of another country such as stocks and bonds.

The foreign direct investor may acquire voting power of an enterprise in an economy through any of the following methods: by incorporating a wholly owned subsidiary or company anywhere, by acquiring shares in an associated enterprise through a merger or an acquisition of an unrelated enterprise participating in an equity joint venture with another investor or enterprise, (Slaughter et al, 2012).

Employment is a relationship between two parties, usually based on a contract, one being the employer and the other being the employee or is the state of being employed; employ; service: to begin or terminate employment.

\section{Strategically FDI comes in three types:}

- Horizontal: where the company carries out the same activities abroad as at home (for example, Toyota assembling cars in both Japan and the UK.

- Vertical: when different stages of activities are added abroad. Forward vertical FDI is where the FDI takes the firm nearer to the market (for example, Toyota acquiring a car distributorship in America) and Backward Vertical FDI is where international integration moves back towards raw materials (for example, Toyota acquiring a tyre manufacturer or a rubber plantation).

- Conglomerate: where an unrelated business is added abroad. This is the most unusual form of FDI as it involves attempting to overcome two barriers simultaneously - entering a foreign country and a new industry. This leads to the analytical solution that internationalization and diversification are often alternative strategies, not complements, (Financial Times, 2013).

\section{Direct Investment Classification}

The classification of direct investment is based firstly on the direction of investment both for assets or liabilities; secondly, on the investment instrument used (shares, loans, etc.); and thirdly on the sector breakdown.

\subsection{Theories and Empirical Studies}

UNITED NATIONS, Jan. 28 (Xinhua) -- Global foreign direct investment (FDI) rose to levels not seen since the start of the global economic crisis in 2008, increasing by 11 percent in 2013 to an estimated 1.46 trillion U.S. dollars, with the lion's share going to developing countries, said a UN report, (2013). FDI flows to developing economies reached a new high of 759 billion dollars, accounting for 52 percent, and transition economies also recorded a new high of 126 billion dollars, 45 percent up from the previous year and accounting for 9 percent of the global total, showed the figures provided by the UN Conference on Trade and Development, (2014).

But developed countries remained at a historical low, or 39 percent, for the second consecutive year. 
They increased by 12 percent to 576 billion dollars, but only to 44 percent of their peak value in 2007, with FDI to the European Union (EU) increasing, while flows to the United States continued their decline. Although inflows to developed countries appear to be recovering over 2012, the picture is mixed: despite positive signs of recovery in some developed country regions such as parts of the EU, flows to the United States failed to reverse their decline, contrary to other signs of economic recovery over the past year, said the report.

Inflows to Japan rose by 61 percent to 2.8 billion dollars, but Australia and New Zealand saw sharp declines of 28 percent to 40 billion dollars and 75 percent to 0.5 billion dollars, respectively, it said. The increase for developing economies was mainly driven by Latin American and the Caribbean, and Africa, while developing Asia, the world's largest recipient region for FDI, saw flows at a level similar to 2012, the report said. Total inflows to developing Asia, comprising East Asia, South Asia, South-East Asia and West Asia, amounted to an estimated 406 billion dollars in 2013, a level similar to 2012.

The performance of sub-regions continues to diverge, with FDI growth rates ranging between 3 percent in South Asia (33 billion dollars), 2 percent in South-East Asia (116 billion dollars), 1 percent in East Asia (219 billion dollars) and a drop of 20 percent in West Asia (down to 38 billion dollars). With inflows to China at an estimated 127 billion dollars, including both financial and non-financial sectors, the country again ranked second in the world, closing the gap with the United States to some 32 billion dollars. India experienced a 17 percent growth to 28 billion dollars, despite unexpected capital outflows in the middle of the year. FDI growth slowed in the Association of Southeast Asian Nations (ASEAN), as inflows to Singapore, the largest recipient in SouthEast Asia, stagnated at 56 billion dollars. But prospects for the group continue to be promising, as more FDI arrives from China and Japan in a wide range of sectors, including infrastructure, finance and manufacturing. West Asia's two main recipients, Saudi Arabia and Turkey, registered significant declines of 19 percent to 9.9 billion dollars and 15 percent to 11 billion dollars, respectively. Turkey witnessed virtually no large FDI deals. In addition, the worsening political instability in many parts of the region have caused uncertainty and negatively affected investment.

Flows to Latin America and the Caribbean increased by 18 percent, the fourth consecutive year of growth, to an estimated 294 billion dollars. While in previous years growth was largely driven by South America, in 2013 Central America and the Caribbean were the main recipients, with increases of 93 percent and 38 percent respectively. Flows to South America declined by 7 percent. The 18-billion-dollar acquisition of Grupo Modelo in Mexico explains most of Central America's increase, while the strong rise in the Caribbean was mainly driven by the British Virgin Islands, said the report. The decline of flows to South America came after three years of strong growth bolstered by the strength of commodity prices that fueled rising profits on investment, as well as reinvested earnings in mining. Decreasing commodity prices seem to have brought a stop to this boom, especially in countries such as Chile, with a drop of 33 percent to 20.4 billion dollars and Peru, with a drop of 2 per cent to 12 billion dollars. In addition, FDI to Brazil, the largest recipient in the sub- region, with 47 percent of South America's total in 2013, declined by a slight 3.9 percent, but remained significant at 63 billion dollars. Nevertheless, this decline should be seen in the context of strong growth in previous years that boosted FDI in Brazil to historical highs.

Inflows to Africa rose by 6.8 percent to an estimated 56.3 billion dollars, due to the strong performance of Southern Africa, including South Africa and Mozambique which experienced record levels of more than 10 billion dollars and 7 billion dollars respectively, as well as lower levels of divestment in Angola compared to previous years. Persistent political and social tensions continued to subdue flows to North Africa, where only Morocco registered solid growth of 24 percent to 3.5 billion dollars. Nonetheless, there are signs that investors are ready to return to the region, with many big cross-border deals targeting Egypt. In Sub-Saharan Africa, Nigeria's lackluster performance (5.5 billion dollars) is the result of a retreat from the oil industry. Transition economies experienced a significant 45 percent rise, reaching a record level of an estimated 126 billion dollars, with Russia jumping by 83 percent to 94 billion dollars, making it the world's third largest recipient for the first time ever, (Mu Xuequan, 2014).

Tanzania and Uganda have widened their lead over Kenya in the race for foreign direct investments (FDI) in the East African region, as lengthy licensing procedures and sluggish commercial dispute settlement turn multinationals away from Nairobi. New data released by the United Nations Conference on Trade and Development (UNCTAD) shows Uganda topped the region in attracting FDI last year, followed closely by Tanzania, on the back of increased investments in the oil and gas sector. FDI to each of the two countries was seven times larger than what Kenya received in 2012, a lag analysts blamed on heightened political tensions and delays in removing cumbersome licensing procedures. In Uganda, most funds went into the oil, gas and mining sectors. "Recent natural resource discoveries contributed to the increase in FDI inflows to East Africa. This includes investments in gas reserves in Tanzania and oil fields in Uganda," said (UNCTAD) in the World Investment Report 2013. Uganda's FDI jumped by 92.51 per cent to \$1.721 billion from \$894 million in 2011, while Tanzania attracted $\$ 1.706$ billion in 2012, a 38.81 per cent increase from the previous year's \$1.229 billion. Meanwhile, Kenya's FDIs dropped by 27.04 per cent to $\$ 259$ million from $\$ 355$ million. Rwanda’s rose by 
50.94 per cent to $\$ 160$ million last year from $\$ 106$ million, while Burundi, which lagged the five East African countries, attracted \$1 million, a 66.67 per cent decrease from \$3 million in 2011.

Thus, the EAC countries received a combined $\$ 3.9$ billion in FDIs last year, a 48.71 per cent rise from the $\$ 2.6$ billion registered in 2011. UNCTAD said interest in the EAC economies among foreign investors is expected to gain fresh impetus in the remaining part of the year, helped by rising confidence in the economy. In Kenya, a peaceful transition after the March 4 elections is expected to trigger more inflows in the second half of the year. But while it lost its grip on FDI inflows, Kenya remained the main investor to other EAC countries, especially in the service sector."Among African investors, KCB was the largest in least developed countries. It announced a total of $\$ 300$ million in investments over 2005 - 2012, with 31 projects in five African countries," said UNCTAD. Kenya's vibrant private sector, advanced infrastructure and skills base have been its main selling points, (The East Africa, 2014).

\section{Contributions of Foreign Direct Investment}

According to Blomström and Kokko, (2003), and Borenzstein, De Gregorio, and Lee (1998). The contributions of FDI to the development of a country are widely recognized as filling the gap between desired investments and domestically mobilized saving, increasing tax revenues, and improving management and technology, as well as labor skills in host countries. These could help the country to fight its way out of poverty (Borenzstein, De Gregorio, and Lee, (1998). According to neoclassical theory, FDI influences income growth by increasing the amount of capital per person. It spurs long-run growth through such variables as research and development (R\&D) and human capital.Through technology transfer to their affiliates and technological spillovers to unaffiliated firms in the host economy,MNCs can speed up the development of new intermediate product varieties, raise product quality, facilitate international collaboration on $\mathrm{R} \& \mathrm{D}$, and introduce new forms of human capital (Ikara, 2003).

Empirical studies suggest that FDI is very important because it provides a source of capital and complements domestic private investment. Many studies (e.g., Blomström and Kokko, 2003; Chen and DØmurger,2002; and FAO, 2001), conclude that FDI contributes to total factor productivity and income growth in host economies, over and above what domestic investment would trigger. These studies find, further, that policies that promote indigenous technological capability, such as education, technical training, and $\mathrm{R} \& \mathrm{D}$, increase the aggregate rate of technology transfer from FDI and that export promoting trade regimes are also important prerequisites for positive FDI impact.

\section{Investment Policy Review - Tanzania (2002)}

In Tanzania, the impact of FDI is, at present, confined to the transfer of technologies and skills. Because of pre1990 policies, foreign companies are concerned about creating jobs which they may not be able to cancel easily should the need arise. Two sectors in which FDI is clearly having an employment impact, however, are mining and tourism.

\section{FDI Role in the creation of employment}

There exists some statistics to support the argument of employment creation by FDIs. UNCTAD (1999a: 3) gives the number of foreign employees employed by each of the world's top 50 MNEs in 1997. The aggregate number is 2,324,300. On a global scale MNEs employed about 45 million persons in 1970s, (Enderwick: 1985). In 1986 the figure was 65 million, which is 3\% of the total world labour force of 2,160 million. (Dunning; 1994). In countries like Liberia, Zaire (Now Democratic Republic of Congo), Taiwan, Malaysia, Singapore, Fiji, Columbia and Argentina, MNEs employed directly 15\% of the labour force. About 73 million people were employed directly by MNEs in 1993 (UNCTAD: 1999a). Indirect FDI employment effect is said to be at least twice as much as the direct ones.

\section{Negative FDI Roles}

FDIs are said to have potentialities of contributing negatively in host economies thereby retarding the socialeconomic transformation and poverty reduction efforts. Some of these negative roles include but are not limited to MNEs influencing policies in their favour; crowding-out local firms; market structure distortion; hampering indigenous entrepreneurial technology; conflicts with local communities and negative health and environmental impacts. Among other negative roles/impacts, some cases of potential and actual conflicts between MNEs undertaking FDIs in Tanzania have been documented by Ngowi (2011). The cases include the case of Kilimanjaro Coffee Plantation Ltd and users of water from Makoyaa stream in Singa Kati Village in Kilimanjaro region; the case of Barrick Gold Mine and users of water from River Tigeti in Mara Region; the case of the planned Uranium mining by Mantra Resources Ltd and water users in Mkuju River and Selous Game Reserve in Namtumbo District Ruvuma region; and the case of Uranium mining in Manyoni Singida with a particular focus on Kinangali ward. Other known cases are those of bio-fuel farming (sugar plantation) and users of water in 
Zumbi small natural lake that serves as a fertile fish-breeding ground in Kipo village in Rufiji; the case of the envisaged largest agricultural FDI in Tanzania by the American-based AgriSol Energy LLC in Mpanda District in Ruvuma region and the case of Usangu rice farming and its impacts on downstream water flow to Ruaha River for hydro electricity production. The negative FDI impacts in these cases imply that these investments also have the potential of derailing the social-economic transformation and poverty reduction efforts. Besides thenegative FDI impacts on social-economic transformation and poverty reduction, there are anumber of emerging current issues in the broader FDI discourse.

\section{Need for Investment policy in Zanzibar.}

Zanzibar is geographically an island; it is nevertheless part of the global village. Its economy must meet the unfolding challenges from globalization and abject poverty among its population. Both of these challenges require speedy transformation including diversification of the economy with the objective of attaining high sustainable and broad based growth. Without attracting huge investments from both foreign and local sources into the economy, it would be almost impossible to meet those challenges, which are clearly stated in the Zanzibar Development Vision 2020. The formulation of this Investment Policy is also due to inadequate economic performance emanating from economic reforms already undertaken. While economic performance emanating from economic reforms responded favourably in terms of GDP growth and reduction in inflation rate among others, such performance is far below the needed economic growth (of about 10 percent) for poverty reduction. The economic reforms by themselves have not attracted huge local and Foreign Investments. Such investments are critical for revitalizing and raising the level of productivity in the leading sectors.

Zanzibar has not received much FDI. Local investments have always been more important for growth than foreign investment. But the little FDI that has come, particularly in the tourism sector, has shown some impact in creation of new and better paid jobs and skills. In terms of trends, FDI into Zanzibar rarely exceeded USD 19 million in any one year. Between 1986 (when the Investment Act was passed) and 2002, Zanzibar received total FDI inflows of \$ 440 million, mainly from Britain, Bahrain, Germany, Italy, Kenya, South Africa, Mauritius and the United Arab Emirates. Most of these investments went into tourism, business services, sea transport and manufacturing; other areas are fisheries, air and agriculture. With the ongoing economic reforms that emphasize the role of the private sector and liberalized markets, more investments are expected to increase. This policy will help increase the speed of investment inflows, (ZRG, 2012).

\section{Contribution of Tourism sector in the GDP}

Tourism's contribution to GDP/GNP has been important in a number of countries. In Bali Island (Indonesia), for example, tourism's contribution to GDP is estimated at between 20 to 40 percent. In Nepal the average contribution of tourism earnings to GDP increased from 1percent in 1974 to 4 percent in 1992. During the 1990s its contribution to GDP was 50 percent in Seychelles and to GNP was 32 percent in Barbados, 18 percent in Maldives, 10 percent in Mauritius and 6 percent in Tunisia (Gee, 1997). Using the Tourist Expenditure model, it is estimated that Tanzania earned USD 1,159.8 million in 2009, out of which Zanzibar earned USD 104.3 million. These earnings accrued from 714,367 and 78,885 international visitor arrivals to Tanzania and Zanzibar, respectively (NBS, 2011).

Incomes for national citizens related to their employment in the tourist sector are also important. The World Trade Organization (WTO) projects that by the year 2005, tourism jobs will increase faster than those in traditional industries by as much as 59 percent. Employment generation by tourism varies from one economy to another depending on, among others, the size and extent of diversification. For example, in larger and more economically diversified islands, such as Jamaica and Puerto Rico, tourism generates about 5 percent of total employment. In smaller islands the share can go up to one-half and above. For example, in Bermuda tourism employs (direct and indirect) 75 percent of the labour force. In other developing countries the figure is not big, as in Cyprus employment creation lies between 5 percent and 10 percent, in Malta 3.5 percent, in Fiji 5 percent, in Tahiti 3 percent and in Bali less than 1 percent. Direct employment in hotels is the most reliable indicator of the sector's contribution to employment, given that data on other direct employment, indirect employment and capital goods employment is hard to get. In Tunisia and Malta, for example, hotels employ about 0.4 persons per bed. In Bali each twin-bedded room averaged 1.5 employees in 1974, but generally hotel employment affected many more persons since employee turnover averaged twenty-one months. Although larger hotels do better here than small ones, other factors such as location, price category, standard of service do matter.

In Tanzania, official data indicate that there were around 157,000 people supposed to be working in the sector in 2001 compared to 96,000 in 1995 (URT, 2002). This may still be an under-estimation, since indirect employment is not taken into account. In 1996 in Zanzibar, tourism employed directly an estimated 4,000 people and 21,000 indirectly. In Kenya tourism is estimated to create about 180,000 formal jobs and 380,000 informal ones, a number that could be doubled if tourism was to be managed and planned more properly, with less crime and political violence interrupting the industry. In Tunisia the service sector's (including tourism) contribution 
to the creation of job opportunities increased from 15 percent of the labour force in 1986 to 36 percent in 1995 . In Seychelles the figure rose from 13.5 percent of the labour force in 1985 to 15 percent in 1994 (United States Bureau of Public Affairs 1987, Focus Multimedia, 1997 and Seychelles Home Page). In Malta direct employment in hotels increased from 7,375 employees in 1990 to 9,533 employees in 2000 (Malta Tourism Authority, 2001). In other countries potential and actual job creation may differ widely, but the net balance may still be worthwhile, in view of limited alternatives for job creation. Tourism has the ability to generate employment both in the formal and informal activities. Evidence indicate that the level of employment in tourism activities is high, for example accounting for 0.5 million jobs in Spain and about 5 million in India (Sinclair, 1998).

\section{Tourism Sector and Investment in Zanzibar}

As a young developing Island, Zanzibar endeavours to build a strong and sustaining economy focused on the development of its natural and human resources. In terms of vision, the Government would like to see a society of educated and healthy individuals with a dynamic culture and sustainable economy. This vision can only be realized if the government works together with the private sector, with each one of them playing a complementary role (RGZ, 2012). Zanzibar has made major progress over recent years towards putting in place a general policy environment that is more favourable for private sector expansion and sustainable economic development. The role of the government in achieving economic development is changing and will continue to change overtime. Under the ongoing economic reforms the governments' role will be confined to the provision of public services; policy management and implementation; monitoring and evaluation of the various policies and strategies and promotion of an enabling environment for private sector investment in production, trade and in the provision of some social and economic services (RGZ, 2012).

According to the Revolutionary Government of Zanzibar (2012), this investment policy is one of the macro policies intended to contribute to the realization of the vision summarized above. It presents an outline of the Island's profile and economic development with regard to the political, economic, infrastructure, communication and legal systems. It also presents both broad and sector-specific investment policy objectives and their accompanying strategies. Current priority sectors for investment have been identified to include: Financial and business services, including offshore and Freeport center activities, Tourism, Agriculture (crops, livestock and fish and marine products), manufacturing, Trade, and transportation.

Tourism is a promising sector for attracting private investments (ibid). Currently the sector contributes between 5 to 8 percent of GDP. Zanzibar has taken institutional measures to develop the tourism sector. As a result, the capacity to accommodate tourists has also increased. The Zanzibar Tourism Development Plan prepared by UNDP in 1983 revealed that in that year there were only 10 unclassified accommodation units, providing 215 rooms and 467 beds. However by 1990 there were 45 hotels and several establishments providing a total of 548 rooms and 1063 beds, which indicates an increase of 39 percent and 44 percent respectively. By the year 2000, the tourism sector has grown considerably and Zanzibar had 173 accommodation units under operation, which provided 6,159 beds. This marked an increase of 82.7 percent of the bed capacity. The strategic economic and social importance of the tourism sector has also grown tremendously. There are numerous and attractive opportunities for investment in the tourism sector. The opportunities range from world class business hotels, conference centres, restaurant/catering facilities, including those providing traditional services, cruise ship transport, diving and game fishing, publication/printing, tourism and hotel training centres, conservation and site attractions.

\section{Trend of Hotels FDI in Zanzibar}

Since 1980s, the world has witnessed rapid and widespread initiatives by governments to involve the private sector in the economy (Weaver, 1995). In deed in the same period we have evidenced a remarkable increase in the flows of FDI in the world economy (Dunning, 2004). The driving forces behind an upsurge in FDIs include general decline in the trade barriers, increased trade liberalization, global political and economic reforms and increased interdependence and linkages across different firms and countries (Hunya etal, 2004). The same pace of growth FDI has also been experienced in tourism and hotel industry (Weaver, 1995). Zanzibar is a semi autonomous state within United Republic of Tanzania.

In early 1990's Zanzibar declared tourism sector as the driver for its economic growth, replacing agricultural sector. Zanzibar is a member of East Africa Community through the umbrella of United Republic of Tanzania. To put it in other ways Zanzibar seems to benefit the large tourism market available in the East African region. Zanzibar has been undertaking major economic reforms since mid 1990's (MoFEA, 2009). Among the initiatives used to promote tourism related foreign direct investment for Zanzibar include conducive macroeconomic environment - such as low and stable inflation, low fiscal deficit, trade and exchange liberalization, steady GDP growth, and maintenance of peace and political stability. Generally, the total foreign private capital in Zanzibar has surged to USD 182.9 million at the end of 2009, from USD 159.6 million 
recorded in 2009 implying an increase of 14.6 percent (ibid). The sectoral distribution of FDI stocks was in favour of service sector, of which tourism services sub-sector accounted for over 80.0 percent due to huge investments in tourist hotels and restaurants etc.

\section{Demographic Characteristics of the Respondents}

The study characterizes the respondents from the village people, officials from the institutions and managers from the hotels at Nungwi whereby it was selected as the main area of the study in Zanzibar. There is no significant difference in demographic characteristics (age, gender and education of villagers, officials from the offices and hotels managers). However, elders from the village are slightly older, where by officials and managers are more educated than those ordinary people. Family sizes are quite large at the village.

\section{RESULTS AND DISCUSSION}

The results in Table 4.1 below indicate that $30(60 \%)$ of the respondents show that local people income position have increased after employed in the tourism sector weather self or by institution itself, to the extent that many local employer have indicated their incomes par day between TZS 5,000 up to 10,000 per day, this figure indicate positive impact on the tourism sector investment in Zanzibar in the creation of employment opportunities to the local people Others reported to receive TZS between 10,000 up to 15,000 per day by $9(18 \%)$, others $3(6 \%)$ reported to receive TZS between 15,000 up to 20,000 per day, also $2(4 \%)$ receive between TZS 20,000 up to 25,000 per day, and those 2 (4\%) who receive between TZS 25,000 up to 30,000 per day, and lastly as reported from the respondents during the questions at the field, there are some people by $4(8 \%)$ who receive 30,000 and above per day.

\section{Table 4.1}

Income position after employment

\begin{tabular}{lll}
\hline & Frequency & Percent \\
\hline 5,000-10,000 par day & 30 & 60 \\
10,000-15,000 par day & 9 & 18 \\
15,000-20,000 par day & 3 & 6 \\
20,000-25,000 par day & 2 & 4 \\
25,000- 30,000 par day & 2 & 4 \\
30,000 and above par day & 4 & 8 \\
Total & $\mathbf{5 0}$ & $\mathbf{1 0 0}$ \\
\hline
\end{tabular}

Research data collected by the researcher (2014)

An overwhelming majority of 50 respondents $31(62 \%)$ who were interviewed reported to be involved as the tour guiding as their main sources of employment in the tourism sector, where by $12(24 \%)$ of the respondents reported to sell masks to the tourists at the hotels and restaurants where by more tourists are available, others include $1(2 \%)$ of the respondents who reported to engage in cooking at hotels and restaurant, $1(2 \%)$ reported to involve in washing clothes at hotels, 2(4) of the respondents are involved in driving visitors car and motorcycles. However there are some of the people, $3(6 \%)$ who are self employed in the small business like selling of fruits, such as mangoes, banana, pineapples, oranges, carrot, and apples, also there are some of them who are cooking in a small hurts as their daily activities.

\begin{tabular}{lll} 
Table 4.2 & Sources of employment in the sector & \\
\hline & Frequency & Percent \\
\hline Selling masks & 12 & 24 \\
Tour guiding & 31 & 62 \\
Cooking & 1 & 2 \\
Washing & 1 & 2 \\
Driving & 2 & 4 \\
Small business & 3 & 6 \\
Total & $\mathbf{5 0}$ & $\mathbf{1 0 0}$ \\
\hline
\end{tabular}

Research data collected by the researcher (2014)

Also the sources of employment as reported by the respondents can be represented by percent in the graph below: As indicated in the graph tour guiding to most of the people is more than 60 per cent, this mean that it is the one of the main activities in the village in the tourism sector, after tour guiding than follow selling masks whereby it shows $24 \%$, others are minor activities which include cooking, washing, driving, and small business. 


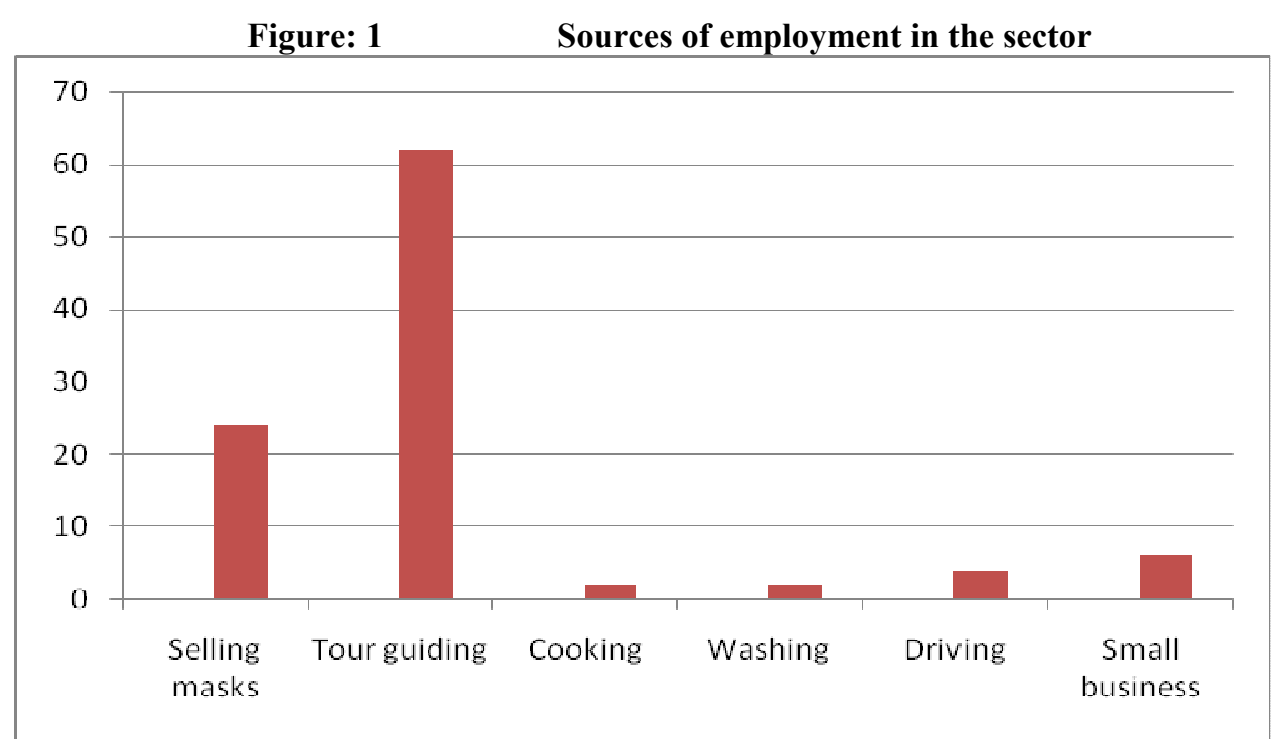

Source: Researcher from the field, (2014)

The study revealed during the interview that respondents primary works ware mainly dominated by fishing activities, where by $38(76 \%)$ reported to invest in before employed in tourism sector. Also farming was another activity that most of local people $12(24 \%)$ in the village were depend upon, building and other activities showed no responses at all.

Table 4.3 Primary works before employment

\begin{tabular}{lcl}
\hline & Frequency & Percent \\
\hline Fishing & 38 & 76 \\
Farming & 12 & 24 \\
Building & - & - \\
Others & - & - \\
Total & $\mathbf{5 0}$ & $\mathbf{1 0 0}$ \\
\hline
\end{tabular}

Research data collected by the researcher (2014)

The data from respondents revealed that the level of income before the employment to the people in tourism were so lower by $(80 \%)$, only $4(8 \%)$ reported that the level of income before employment opportunities were high and only $6(12 \%)$ their responses were on the level of income before employment were normal. From the above data from the respondents mean that there are massive increase of income level to the people after they score employment activities, the increase help the people to afford at the maximum level of their daily social needs, such as sending their children to school, paying health fees and even buying foods. In other way round there those few people who reported that their income level were high for (\%8) even before employment, these depict rich people in the village who depend in other employment opportunity rather from the tourism employment. However other reported that the income level before employment were normal for $12 \%$, it means that there those who live in very prestigious life and they see the life situation was so normal for them even they are employed or not.

Table 4.4 Income level before employment

\begin{tabular}{lcl}
\hline & Frequency & Percent \\
\hline Normal & 6 & 12 \\
High & 4 & 8 \\
Lower & 40 & 80 \\
Total & $\mathbf{5 0}$ & $\mathbf{1 0 0}$
\end{tabular}

\section{Research data collected by the researcher (2013)}

The income level before employment in tourism can be also represented in the following figure below. The large portion of the figure below is field by the all respondent who reported that their income level had lowered for about $80 \%$, other including $12 \%$ for normal responses and $8 \%$ for high responses during the interview. 


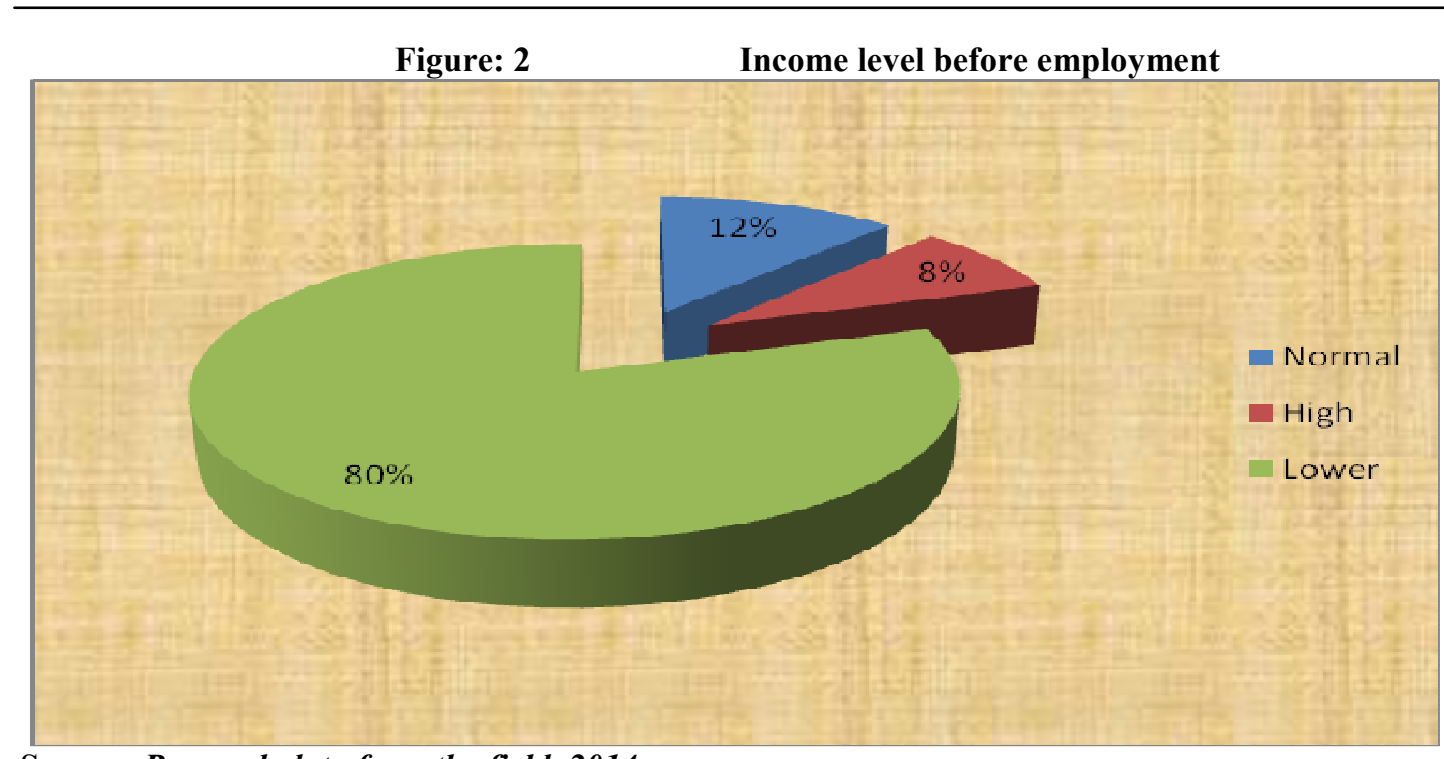

\section{Source: Research data from the field, 2014}

Responses on the factors for maximization of the economic development from tourism sector investment were mainly based on the tax control where by 35(70\%) reported that the government must control the taxes to those investors invested in tourism sector, this will help the government reach its millennium development goals, in that case it will able to reduce the poverty in the country and increase the opportunity of employment to the people by fund rising to other sectors in the country. Also data from the field for $12(24 \%)$ show that there is need to engage from external investors in the tourism sector, this will help the country to earn more from foreign money and will help to improve its economic development, where by only $3(6 \%)$ reported to that there is the need to promote domestic investors to invest in tourism sector for the benefit of their own country.

\section{Table 4.5 Factors to improve economic development}

\begin{tabular}{lll}
\hline & Frequency & Percent \\
\hline Control taxes & 35 & 70 \\
Engage more from external investors & 12 & 24 \\
Engage more from domestic investors & 3 & 6 \\
Total & $\mathbf{5 0}$ & $\mathbf{1 0 0}$ \\
\hline
\end{tabular}

\section{Research data collected by the researcher (2014)}

Relatively stable political conditions in Zanzibar received significant attention from the foreign hotel investors. In other words there are (is) statistically relationship between political stability and inflow of foreign investors. A dramatic change that has occurred in Zanzibar's political and economic environment has motivated multinational tourism firm to operation in Zanzibar through FDI entry mode. In that case most of the respondents $29(58 \%)$ reported that there is a need to improve more political stability in the country as a strategy to be used to ensure factors for the success in economic development especially in the tourism sector investment in the country. Other $13(26 \%)$ reported that there is the need for the government to be stable in the direct tax collection to both internal and external investors to prevent the loss of government revenue. In other way respondents $8(16 \%)$ reported that there is a need also to improve more economic relationship with other people in order to develop mutual benefits with other countries.

Table 4.6 Strategies to be used

\begin{tabular}{lll}
\hline & Frequency & Percent \\
\hline Direct tax collection & 13 & 26 \\
Political stability & 29 & 58 \\
Improve its economic relationship & 8 & 16 \\
Total & $\mathbf{5 0}$ & $\mathbf{1 0 0}$ \\
\hline
\end{tabular}

\section{Research data collected by the researcher (2014)}

Majority of the respondents who were asked on which stakeholders were to be involved, 21(42\%) reported that both government and non-government agencies must be involved in the sectors and play fully 
responsibilities in the negotiation with the investors and ensure that our country develop both socially and economically depending in the tourism sector investment, only $16(32 \%)$ government agencies should be fully involved, other 13(26\%) non-government stakeholders must be involved in the tourism sector development.

Table 4.7

Stakeholders to be involved

\begin{tabular}{lll}
\hline Description & Frequency & Percent \\
\hline Government agencies & 10 & 32 \\
Non-government agencies & 13 & 26 \\
Both & 21 & 42 \\
Total & $\mathbf{5 0}$ & $\mathbf{1 0 0}$ \\
\hline
\end{tabular}

\section{Research data collected by the researcher (2014)}

As shown in the table 4.8 below. Tourism investment in the country reported to have some negative costs to the public especially to those areas where by tourists live, according to the respondents, $19(38 \%)$ tourists has become a source of moral distortion not only in one village but also the entire country, from the responses most of the people especially have no manner neither women nor man they wear in shorts and loosed clothes which is believed to be imitated from the foreigners, However prostitution for $18(36 \%)$ has took a second lead as the main problems which was brought about the tourists destination in Zanzibar's hotels and beaches, the situation negatively invited the large group of our people to engage in prostitution practices as their main sources of getting their incomes. Not only that but also the tourism sector investment in Zanzibar has led to the spread of dangerous diseases like HIV Aids, Environmental pollution is another issue, 1(2\%) reported, this was caused by the coming of investors in the country, because most of the investors need large plots in order to build large hotels, lodges restaurants and guesthouses, in that case they need bare land the situation which led to the cutting down the trees and extracting tones of sends and stones to be used as constructions materials and subsequently turn into worse situation to our environment. Other $1(2 \%)$ reported that the tourism sector investment in the country has caused the loss of jobs to our people this is due to the fact that most of the foreign affiliate they bring their own workers from outside, some of them they employ the people from Kenya and Uganda believing that Zanzibaries feel uncomfortable being employed in the tourists hotels because of their faith.

Table 4.8 Public costs related to the tourism investment

\begin{tabular}{lll}
\hline Description & Frequency & Percent \\
\hline Moral distortion & 19 & 38 \\
Spread of diseases & 11 & 22 \\
Environmental pollution & 1 & 2 \\
Prostitution & 18 & 36 \\
Loss of job & 1 & 2 \\
Total & $\mathbf{5 0}$ & $\mathbf{1 0 0}$ \\
\hline
\end{tabular}

Research data collected by the researcher (2014)

Public costs related to the tourism can also be represented in the following figure below:

Figure: 3

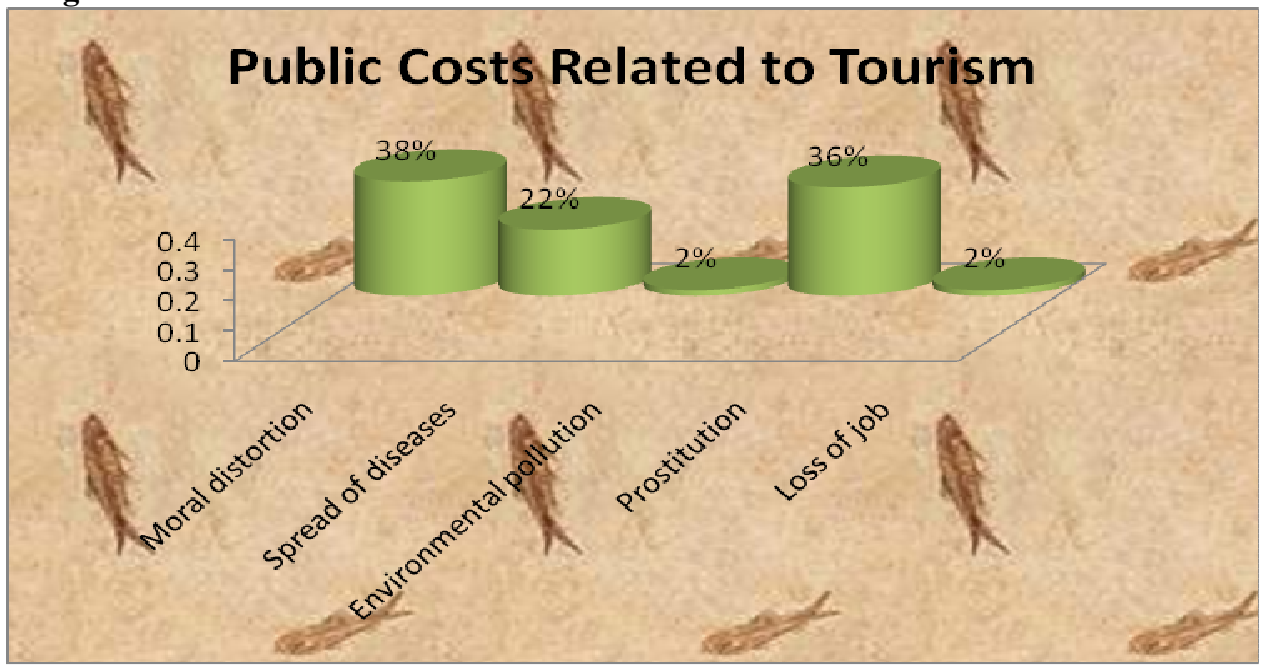

Source: Research data from the field, 2014 
The researcher interviewed officials from Zanzibar Investment Promotion Authority (ZIPA) who were asked to explain factors that can help the Revolutionary Government of Zanzibar to minimise its economic losses from tourism sector and some of the responses are as reported below:

Respondents reported that, first Zanzibar is a good place for tourism destination, if we maintain peace and security in the country Government can minimize its economic losses from tourism sector. In the extent that many internal and external tourists will be more interested visiting Zanzibar as they will be more secure compared to other countries, hence the Government will benefit more from foreign currencies and improve employment opportunities to its local people. Second Revenue collection, we have many hotels and restaurants in Zanzibar, but still collections are very low, therefore the government should ensure purposely collect its revenues from both local and foreign affiliates, this will help the Revolutionary Government of Zanzibar to sponsor its budget. Third, construction and reconstruction of infrastructures, this will be more impressive for our foreigners if they visit and see we have better roads, lodges and hotels in the country, because if our infrastructure will be rough we will get economic losses due to the fact that many tourists will not visit our country. Other official from ZIPA mentioned the following strategies the Revolutionary Government of Zanzibar can use to prevent economic losses from tourism sector, these strategies including; Application of law and bylaws for those in one way or another endangers the peace and security of the country, fighting against corruption, and proper collection of government revenues from tourism sector.

As reported from official respondents which stakeholders should be involved in order for the Revolutionary Government of Zanzibar can use as a bridge to prevent economic losses from tourism sector, and the responses were all the stakeholders should be involved, where by each one should responsible and accountable to its position as allocated, mentioning government agencies, non-government agencies, community and other stakeholders. One of the Manager reported to say at the field during the interview on the reaction of the community related to the problem of tourism sector investment in the country, that many people were convicted to the burning of the tourists harts and rest places of the visitors and this has become very big problem in most of the villages in Zanzibar surrounded by the beaches where by many tourist are available in the country. Also some of the people they commit crimes such as theft and burglary of our visitors, the situation that cost much our popularity and attraction of our business activities. Another manager reported to say on the solution to mitigate these problems is to improve community security, government involvement on the situation by introduction of the strong laws for those convicted to the tourist crimes.

The researcher has observed many things during the field, he observed many people men and women working in different areas such as, travelling with tourists in the visitors car from one place to another, also researcher has seen tourist cross the see from one small islands to onether for visiting finding the wonders of Zanzibar Island blessed with white and wide beaches coral reef and wonderful fishes in the sea, the tourists used special fibres playing and crossing the sea.

\subsection{CONCLUSIONS}

The FDI inflow in the tourism sector contribute much on the creation of employment to the local people not only in the area of study but also the entire country of Zanzibar where tourists are their main preferred destination. In fact the tourism sector investment represents a vital contribution not only in the creation of employment opportunities to the people but also as a major source of economic development of a country if the strong policies and strategies guiding the tourism sector will be improved in the country.

\subsection{RECOMMENDATIONS}

Tourism and its related activities should be promoted not only in the areas of study, but also in other parts of the country with tourist attractions. Promotion of domestic tourism need to be encouraged. Employment opportunities for the locals are observed to be in the low cadres with low skills and remuneration. In order to increase the impact of tourism on the creation of the employment opportunities to the local people, there is need to institute and promote training programmes that would ultimately provide chance for the locals to be employed in high cadres with high pay. Cultural tourism is emerging as an important tourist attraction with no significant investment requirements. Given that in most parts of rural Zanzibar the majority have low education and lack of capital, this type of tourism need to be encouraged in order to contribute towards more employment opportunities. The negative impacts such as environmental problems, cultural pollution and immoral behaviour, which are a cost and hence reducing the positive impacts, or benefits from tourism must be dealt with. Thus, whereas there is need to optimise the benefits from tourism, measures and policies to minimize cultural pollution, environmental conservation and protection need to be promoted and supported in tourist areas for sustainable development.

\section{REFERENCES}

Africa's Hopes and Dilemma". ATPS Special Paper Series No. 16; ATPS Communications Department, 
Nairobi,Kenya.

Blomström Magnus, and Kokko Ari, (2003). “The Economics of Foreign Direc Investment Incentives". EIJS

Working papers 168. Retrieved from http://www.hhs.se/eijs

Cases of Controversial Water Issues in FDI Projects in Tanzania. Paper presented at the International Workshop on "Poverty, Water \& Local Development", Kampala, Uganda, November 28th-30th, 2011.

Dunning, J., \& Narula, R. (2004). Multinationals and industrial competitiveness. A new agenda. Cheltenham, UK.

Definitions of Foreign Direct Investment (FDI): a methodological note Maitena Duce1 Banco de España2 Final draft July 31, 2003.

Global foreign direct investment rises to pre-crisis levels, UN reports

English.news.cn 2014-01-29 06:45:26

Hunya, G. (2004): FDI in Small Countries: The Baltic States; WIIW Research Reports/ 307.

Ikara Moses, M., (2003). "Foreign Direct Investment (FDI), Technology Transfer, and Poverty Alleviation:

Sinclair, M. T., Alizadeh Parvin and Elizabeth Atieno Onunga (1995). "TheStructure of International Tourism and Tourism Development in Kenya", in D. Harrison (ed.), Tourism and the Less Developed Countries. N.p: n.p

Slaughter and May (2012). "Legal regimes governing Foreign Direct Investment (FDI) in host countries".

MoFEA, (2009). The Zanzibar Strategic Plan for Economic Growth and Poverty Reduction.

Ngowi, H. P (2011), The Water Question in Foreign Direct Investments (FDIs): Selected

United Nations Conference on Trade and Development (2002). 'Investment Policy Review Tanzania'. United

Nations, New York and Geneva. UNCTAD/ITE/IPC/Misc. 9.

Zanzibar Revolutionary Government: Zanzibar Investment Policy, (2012).

\section{Internet Sources}

http://earthmind.net/fdi/ilo/fdi-and-jobs.pdfFDI AND JOBS

Weaver, D. B. (1995). Alternative tourism in Montserrat. Tourism Management, 16,593-604.

http://www.zanzibarinvest.org/investment_policy.pdf Retrieved on April 18-4-2013

UNCTAD (2010). Global FDI Trends

http://www.fdi.net/documents/WorldBank/databases/tanzania/TourismSect Overview.pdf MIGA.

FAO, (2001). "Agricultural Investment and Productivity in Developing Countries". Economic and Social Development Paper 148. Retrieved from. www.fao.org 
The IISTE is a pioneer in the Open-Access hosting service and academic event management. The aim of the firm is Accelerating Global Knowledge Sharing.

More information about the firm can be found on the homepage:

http://www.iiste.org

\section{CALL FOR JOURNAL PAPERS}

There are more than 30 peer-reviewed academic journals hosted under the hosting platform.

Prospective authors of journals can find the submission instruction on the following page: http://www.iiste.org/journals/ All the journals articles are available online to the readers all over the world without financial, legal, or technical barriers other than those inseparable from gaining access to the internet itself. Paper version of the journals is also available upon request of readers and authors.

\section{MORE RESOURCES}

Book publication information: http://www.iiste.org/book/

Academic conference: http://www.iiste.org/conference/upcoming-conferences-call-for-paper/

\section{IISTE Knowledge Sharing Partners}

EBSCO, Index Copernicus, Ulrich's Periodicals Directory, JournalTOCS, PKP Open Archives Harvester, Bielefeld Academic Search Engine, Elektronische Zeitschriftenbibliothek EZB, Open J-Gate, OCLC WorldCat, Universe Digtial Library, NewJour, Google Scholar

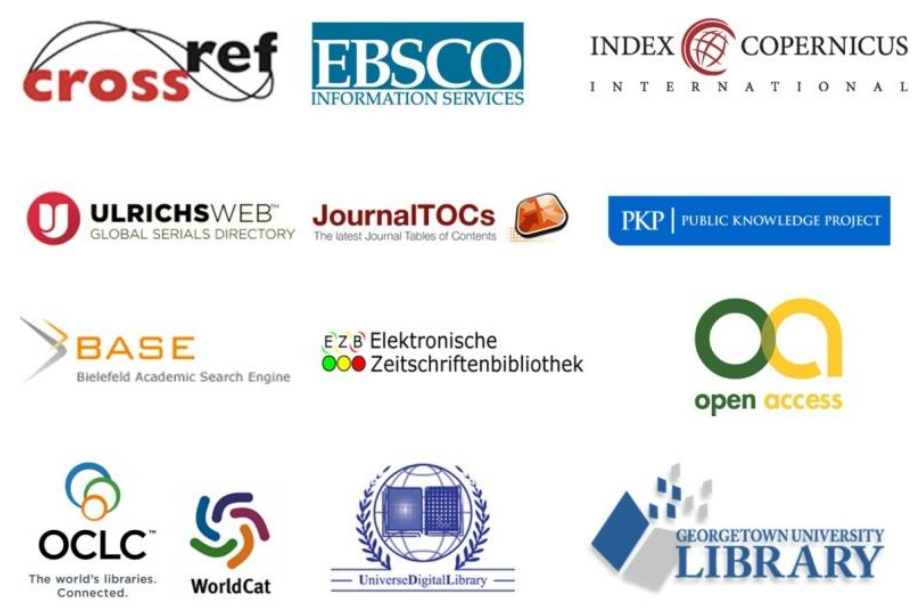

